\title{
Familial clubfoot due to 17q23.1q23.2 microduplication
}

INSERM

\section{Source}

INSERM. (1999). Orphanet: an online rare disease and orphan drug data base. Familial clubfoot due to 17q23.1923.2 microduplication. ORPHA:238578

17q23.1-q23.2 microduplication is a newly described cause of familial isolated clubfoot. 